\title{
MONTE CARLO METHOD OF SHIP'S UNDERKEEL CLEARANCE EVALUATION FOR SAFETY OF FERRY APPROACHING TO YSTAD PORT DETERMINATION
}

\section{METODA MONTE CARLO DO OKREŚLANIA REZERWY WODY POD STĘPKA DLA ZAPEWNIENIA BEZPIECZEŃSTWA PROMÓW NA PODEJŚCIU DO PORTU YSTAD}

\author{
Lucjan Gucma ${ }^{1}$, Marta Schoeneich ${ }^{2}$ \\ Maritime University of Szczecin \\ Wały Chrobrego1-2, 70-500 Szczecin, Poland \\ E-mails: (1)lucek@am.szczecin.pl (2) martas@am.szczecin.pl
}

\begin{abstract}
The paper is concerned with the analysis of simulation research results of newly design Piast ferry entering to modernized Ystad Port. The ship simulation model is described. After execution of real time simulations the Monte Carlo method of underkeel clearance evaluation is applied to asses the probability of ferry touching the bottom. The results could be used in risk assessment of ships entering to the ports.
\end{abstract}

Keywords: Ship's simulation model, Monte Carlo method, underkeel clearance.

Streszczenie. W artykule zaprezentowano analizę wyników badań symulacyjnych wejść nowoprojektowanego promu Piast do modernizowanego portu Ystad. Przedstawiono także model symulacyjny statku wykorzystany $\mathrm{w}$ badaniach. Po przeprowadzeniu symulacji w czasie rzeczywistym, metoda Monte Carlo określania zapasu wody pod stępką została wykorzystana do oszacowania prawdopodobieństwa kolizji z dnem akwenu. Uzyskane wyniki mogą być wykorzystane do oceny ryzyka statków podchodzących do portów.

Slowa kluczowe: Model symulacyjny statku, Monte Carlo, rezerwa wody pod stępką. 


\section{Introduction}

Underkeel clearance (UKC) is most important factor which determines the possibility of ships hull touching the bottom [5] therefore it is one of the basic elements which decide of navigation safety in restricted waters. The basic navigator's responsibility is to keep safe underkeel clearance in any conditions.

The researches presented in this study are aimed towards determination of UKC of ferries on approach to Ystad Port. The UKC depends on squat which main factor is speed of ships. On approach to Ystad in unfavourable wind conditions speed of ferries cannot be decreased due to lack of maneuverability and this phenomenon is carefully investigated in the paper.

\section{Ystad Port entering simulation research}

The main scope of the simulation research consisted of the following issues:

a) Determination of optimal parameters of:

- approach channels to reconstructed port of Ystad with respect to shape, width and depth,

- inner and outer port breakwaters with respect to its shape with respect to waving in port;

- turning places with respect to its shape and optimal depth;

- two new berthing places in inner port in respect to its shape, length, depth, maximal energy of ships contact, maximal speed of ships propeller and bowthruster streams in the bottom.

b) Determination of safety conditions of port operation in respect to:

- admissible meteorological conditions for given kind of ships and maneuvers;

- other navigational conditions and limitations like presence of other ships on berths, use of position fixing systems on approach, navigational markings, vessel traffic service.

c) Determination of maneuvering procedures during berthing and unberthing for different kind of ships and propulsion systems.

d) Determination of underkeel clearance by Monte Carlo method.

e) Determination of usage of main engine during entrance.

f) Determination of ferry distances to the most dangerous objects.

g) Carrying out most typical emergency runs and describe necessary emergency action for the captains. 
Monte Carlo method of ship's underkeel clearance evaluation for safety.

Metoda Monte Carlo do określania rezerwy wody pod stepka ...

\section{Simulation model}

The model used in research is based on modular methodology where all influences like hull hydrodynamic forces, propeller drag and steering equipment forces and given external influences are modeled as separate forces and at the end summed as perpendicular, parallel and rotational ones [1].

The model is operating in the loop where the input variables are calculated instantly (settings and disturbances) as the forces and moments acting on the hull and momentary accelerations are evaluated and speeds of movement surge, sway and yaw. The most important forces acting on the model are:

- thrust of propellers

- $\quad$ side force of propellers;

- $\quad$ sway and resistant force of propellers;

- bow and stern thrusters forces;

- current;

- wind;

- ice effects;

- moment and force of bank effect;

- shallow water forces;

- mooring and anchor forces;

- reaction of the fenders and friction between fender and ships hull;

- tugs forces;

- other depending of special characteristics of power and steering ships equipment.

The detailed diagram of model of the ship maneuvering simulation model is presented in Figure 1 .

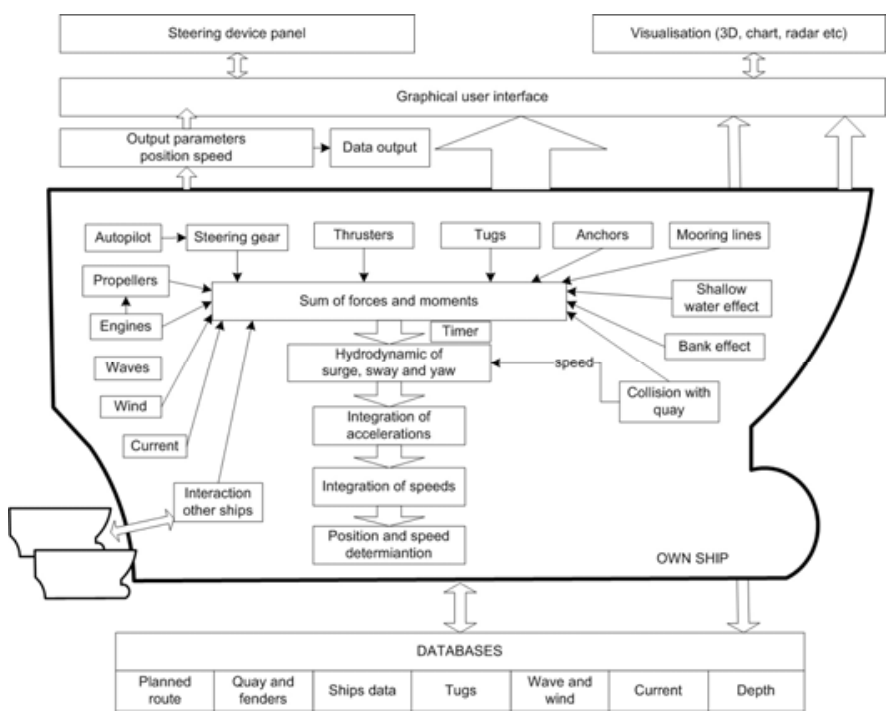

Fig. 1 The main diagram of simulation model 


\section{The Monte Carlo method of underkeel clearance on ferry approach}

The stochastic model of under keel clearance evaluation was presented in [2]. It is based on Monte Carlo methodology where overall ships underkeel clearance is described by following mathematical model ( Figure 2):

$$
U K C=\left(H_{0}+\sum \delta_{H o i}\right)-\left(T+\sum \delta_{T i}\right)+\left(\Delta_{S w a}+\sum \delta_{S w i}\right)+\delta_{N}
$$

where:

$\delta_{H o i}$ - the uncertainties concerned with depth and its determination,

$\delta_{T i}-$ the uncertainties concerned with draught and its determination,

$\delta_{\text {Swi }}$ - the uncertainties concerned with water level and its determination.

$\delta_{N} \quad$ - navigational and manoeuvring clearance.

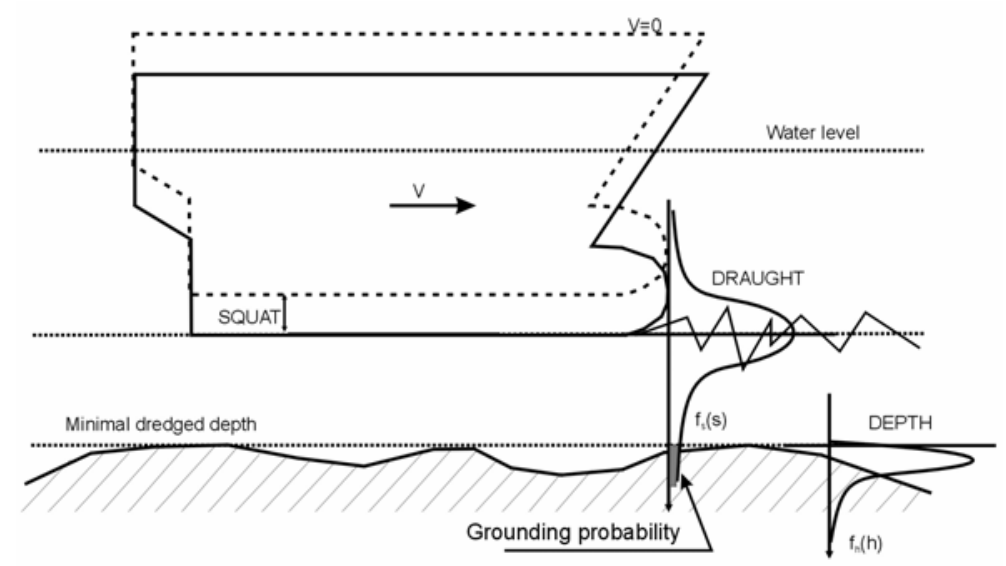

Fig. 2 Concept of probabilistic underkeel clearance of ships determination

The final model takes into account depth measurement uncertainty, uncertainty of draught determination in port, error of squat determination, bottom irregularity, tides and waves influence are deciding factors for underkeel clearance of ships. Program is capable to consider above mentioned uncertainties using distributions and their parameters. The following parameters are randomly selected from their distributions:

- depth $-h_{i}$ (averaged in following sections $-100 \mathrm{~m}, 0 \mathrm{~m},+100 \mathrm{~m}, 200 \mathrm{~m}, 300 \mathrm{~m}$ from breakwater),

- sounding error- $\delta_{B S_{i}}$,

- mudding component clearance - $\delta_{Z_{i}}$,

- draught determination error $-\delta_{T_{i}}$, 
- ship's heel error - $\delta_{P_{i}}$.

\section{Random draught module}

User-entered draught is corrected for draught determination error value and ship's heel error. Iterated draught $\left(T_{i}\right)$ is calculated as follows:

$$
T_{i}=T+\delta_{T_{i}}+\delta_{P_{i}}
$$

where:

$T$ - ships draught $[\mathrm{m}]$ assumed as $6.3 \mathrm{~m}$,

$\delta_{T_{i}}$ - draught determination error (assumed as $+/-0.05 \mathrm{~m}$ ),

$\delta_{P_{i}}$ - ships heel error (assumed as $+/-3$ degrees).

\section{Water level module}

Water level $P W_{i}$ can be automatically load from online automatic gauges if such exists (Polish solution). In these researches the level was modelled as normal cut distribution with parameters $(0,+/-0.1 \mathrm{~m})$.

\section{Depth module}

Depth $h_{i}$ was assumed as constant in given sections (it varies from 9 before and near breakwater to $8.5 \mathrm{~m}$ inside the port).

\section{Squat module}

Squat (ship sinkage due to decrease of water pressure during movement) is calculated in three stages. First module calculates squat with analytical methods used to obtain moving vessel squat (Huusk, Milword 2, Turner, Hooft, Barrass 1, Barrass 2). Next standard errors of each method are applied. Squat model selection and their standard errors were verified by GPS-RTK experimental research [3][6]. As a result of the experiment uncertainty of each model was assessed and each squat method assigned weight factor. Method's weights and statistical resampling bootstrap method are used later on to calculate final ship's squat.

\section{Underkeel clearance module}

Underkeel clearance $Z_{\mathrm{i}}$ is determined by using draught, depth, water level and squat results which were calculated before. Underkeel clearance is defined as:

$$
Z_{i}=\left(h_{i}+\delta_{Z_{i}}+\delta_{B S_{i}}\right)-\left(T_{i}+O_{i}+\delta_{N}+\delta_{W P_{i}}+\delta_{F}\right)
$$


where:

$h_{i}$ - up-to-date depth in each iteration in sections (sounding from October 2007),

$\delta_{Z_{i}}-$ mudding component clearance (normal cut distribution with 0 and $+/-$ $0.1 \mathrm{~m})$,

$\delta_{B S_{i}}$ - sounding error (normal cut distribution with 0 and $+/-0.1 \mathrm{~m}$ ),

$T_{i}$ - ships draught with its uncertainty $(0,+/-0.05 \mathrm{~m})$,

$O_{i}$ - iterated squat (bootstrap model),

$\delta_{N}$ - navigational clearance $(0 \mathrm{~m})$,

$\delta_{W P_{i}}$ - height of tide error $(0 \mathrm{~m})$,

$\delta_{F}$ - wave clearance (wave height assumed as $\mathrm{h}=0.4 \mathrm{~m}$ before breakwater, $\mathrm{h}=0.2 \mathrm{~m}$ in the breakwater and $\mathrm{h}=0 \mathrm{~m}$ inside, direction from ferry traverse).

\section{General simulation research assumptions}

Simulation research is based on performance of maneuvering trial series (inbound/outbound) of significant number for detailed variants. These variants determines given problem. Comparing of results for each variant is done with use of navigational safety criteria.

Variants of researches were determined with following circumstances:

- exploitation conditions of given berth,

- previous researches results ( $\mathrm{m} / \mathrm{f}$ Polonia inYstad port),

- assumptions of analysis,

- investigated area,

- given vessels types,

- navigation conditions,

- manoeuvering tactics.

Simulations were conducted on PC based simulator described which interface is presented in Fig.3. It allows controlling and observing several ships parameters. Captains performed the simulations. In total 6 series were executed each consists of 15 trials. The simulation data were recorded and in the next step used as input data for Monte Carlo model. 


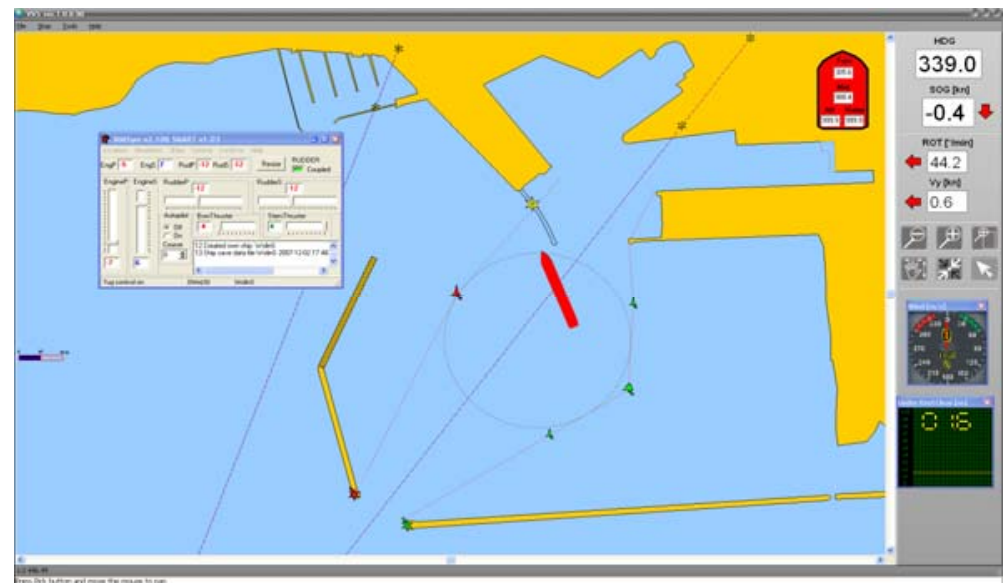

Fig. 3 Interface of simulation model ferry entering to Ystad

\section{Results of Monte Carlo method of ship's underkeel clearance evaluation}

Figures $4 \mathrm{a}$ and $4 \mathrm{~b}$ show speed which has the ferry on approach in particular simulation trials in two different wind conditions.

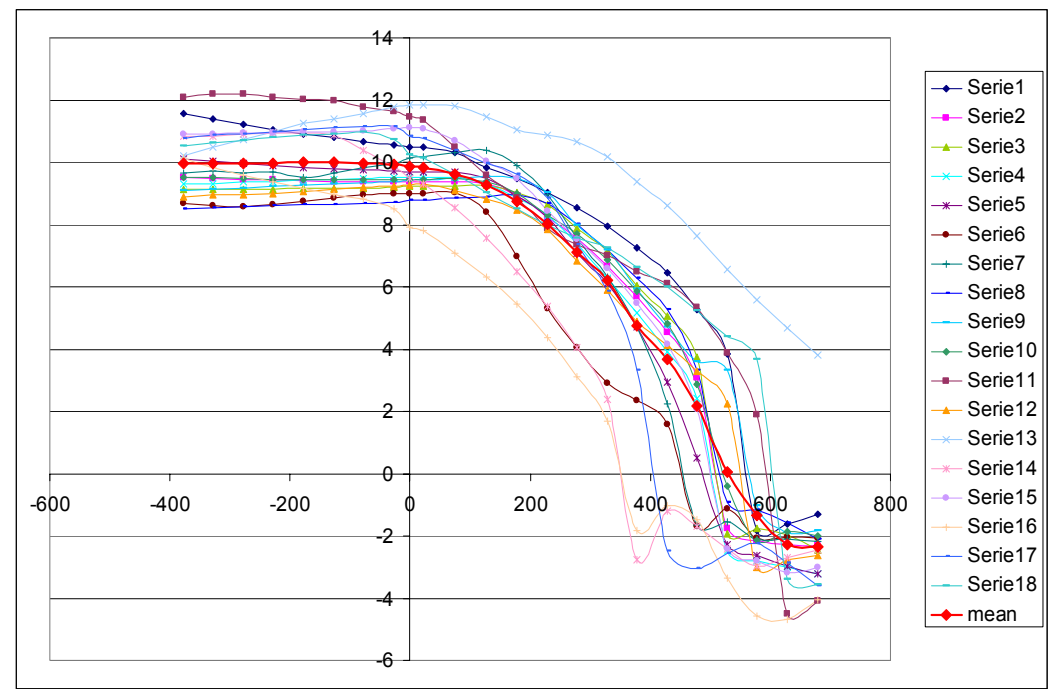

Fig. 4a Speed of ferry in knots on approach with E20m/s wind ( $x=0$ outer breakwater) 


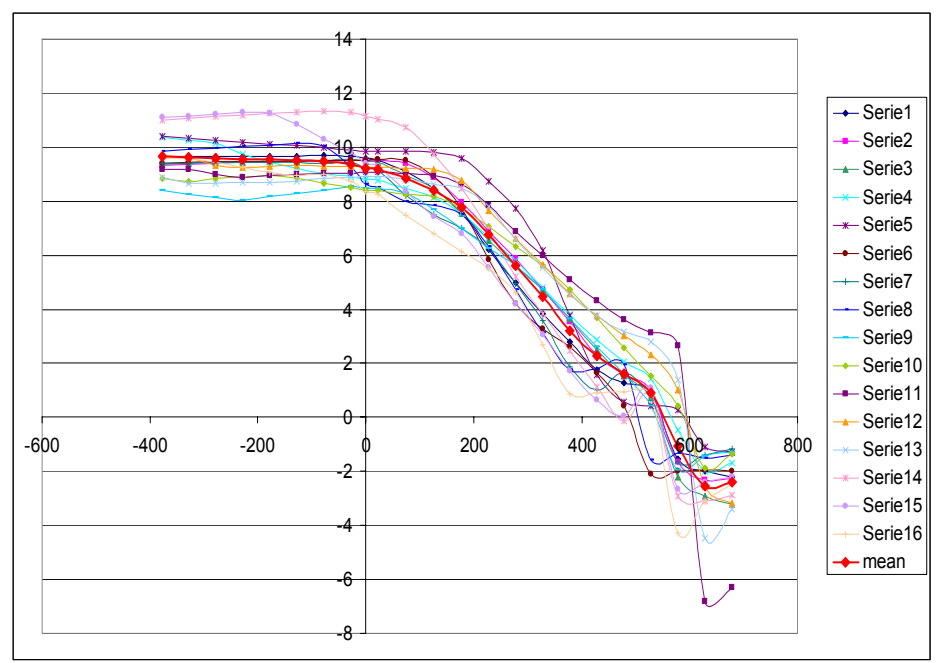

Fig. 4b Speed of ferry in knots on approach with $\mathrm{W} 20 \mathrm{~m} / \mathrm{s}$ wind $(\mathrm{x}=0$ outer breakwater)

The most important result is the probability that clearance is less than zero. This is the probability of accident due to insufficient water depth. The probabilistic model of underkeel clearance [4] was used for these probability determinations. Histograms of simulated UKC by Monte Carlo method in different parts of Ystad Port are presented in Figure $5 a$ and $5 b$.

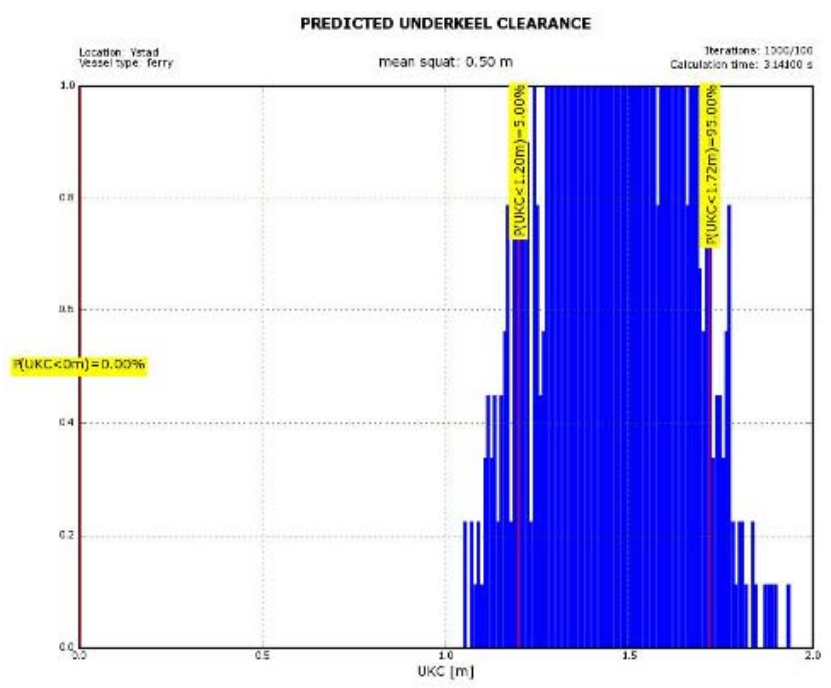

Fig. 5a Histogram UKC and squat value $130 \mathrm{~m}$ before heads $/$ sea wave $=0,4 \mathrm{~m} /$ 


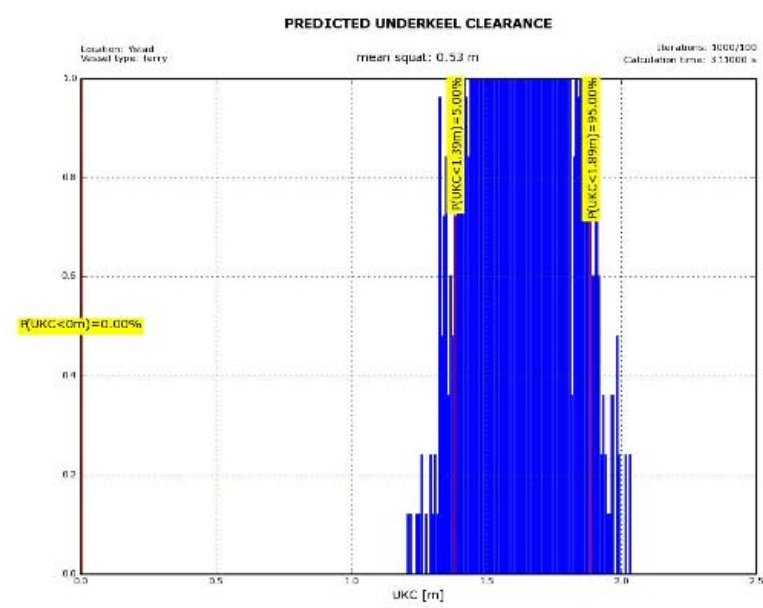

Fig. 5b Heads: Histogram UKC and squat value $/$ sea wave $=0,2 \mathrm{~m} /$

Distributions show that probabilities of touching the bottom in all cases are near zero.
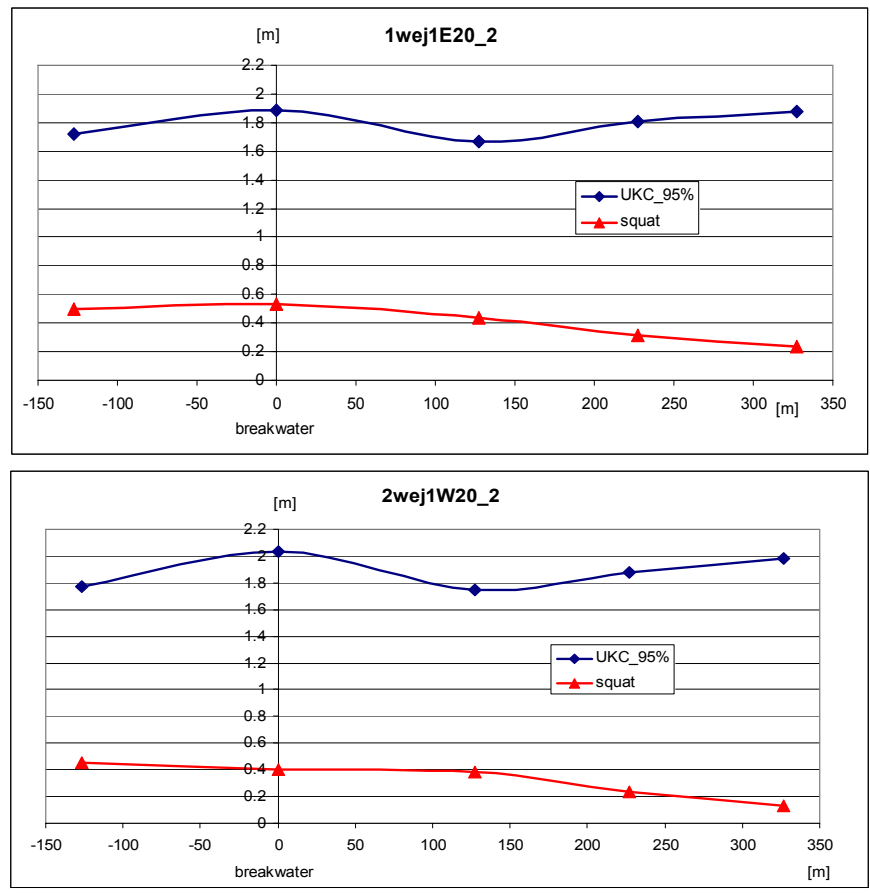

Fig. 6 UKC on 95\% level of confidence of Piast ferry approaching with E20m/s and $\mathrm{W} 20 \mathrm{~m} / \mathrm{s}$ wind $(\mathrm{x}=0$ means outer breakwater $)$ 


\section{Conclusions}

The presented methodology of UKC calculation can be used for safety determination and risk analyses of ships in ports and approaches.

UKC calculated by Monte Carlo in Ystad Port by Monte Carlo model is above $1.6 \mathrm{~m}$ in worst assumed conditions.

\section{References}

1. Gucma L., Gucma M., Przywarty M., Tomczak A. Eksperymentalne określanie rozkładów osiadania i trymu promu morskiego m/f Jan Śniadecki na podejściu $i$ w porcie Świnoujście metodami RTK Proceedings of the XV-th International Scientific and Technical Conference "The Role of Navigation in Support of Human Activity on the Sea", Gdynia, 2006.

2. Gucma L., Risk Modelling of Ship Collisions Factors with Fixed Port and Offshore Structures, Maritime University of Szczecin, Szczecin 2005.

3. Gucma L., Schoeneich M. Określanie niepewności metod osiadania na podstawie badań rzeczywistych przeprowadzonych na promie m/f Jan Śniadecki $w$ porcie Świnoujście, Proceedings of the XV-th International Scientific and Technical Conference "The Role of Navigation in Support of Human Activity on the Sea", Gdynia 2006.

4. Gucma L., Schoeneich M., Probabilistic Model of Underkeel Clearance in Decision Making Process of Port Captain. Monograph- Advances in Marine Navigation and Safety of Sea Transportation TransNav'2007, Gdynia 2007.

5. Gucma S., Jagniszczak I., (2006) Nawigacja morska dla kapitanów, Szczecin.

6. Research work Determination of squat of $\mathrm{m} / \mathrm{f}$ Śniadecki by RTK method in Świnoujście Port. Maritime University of Szczecin, Szczecin 2006.

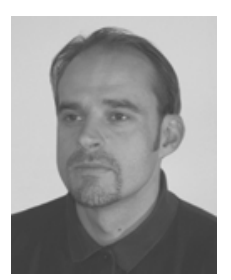

Lucjan GUCMA is professor in Navigational Faculty of Maritime University of Szczecin, Poland. In 2004 he became the Director of Marine Traffic Engineering Institute. His main scientific interest is concern with probabilistic method in safety of ships assessment on restricted water areas. He has published the book titled "The models of risk factors of ship collision with fixed offshore and port structures" and more than 50 papers in journals and conference proceedings.

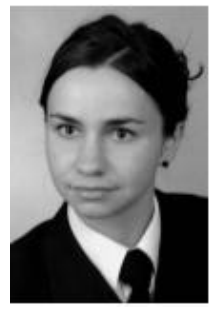

Marta SCHOENEICH, (MSc.) Maritime University of Szczecin, Poland. Member of Maritime Traffic Engineering Research Team. Specialization: Marine Traffic Engineering, ship's underkeel clearance research, probabilistic methods. She is an author of several scientific publications. 